\title{
Regional genetic structure in the Magellanic penguin (Spheniscus magellanicus) suggests metapopulation dynamics
}

\author{
Juan L. Bouzat \\ Brian G. Walker \\ Fairfield University, bwalker@fairfield.edu \\ P. Dee Boersma
}

Follow this and additional works at: https://digitalcommons.fairfield.edu/biology-facultypubs Copyright 2009 University of California Press for American Ornithologists' Union (AOU). This article is also electronically available via Caliber, JSTOR and AnthroSource.

\section{Peer Reviewed}

\section{Repository Citation}

Bouzat, Juan L.; Walker, Brian G.; and Boersma, P. Dee, "Regional genetic structure in the Magellanic penguin (Spheniscus magellanicus) suggests metapopulation dynamics" (2009). Biology Faculty Publications. 28.

https://digitalcommons.fairfield.edu/biology-facultypubs/28

\section{Published Citation}

Bouzat, JL, BG Walker and PD Boersma. 2009. Regional genetic structure in the Magellanic penguin (Spheniscus magellanicus) suggests metapopulation dynamics. Auk 126 (2):326-334.

This item has been accepted for inclusion in DigitalCommons@Fairfield by an authorized administrator of DigitalCommons@Fairfield. It is brought to you by DigitalCommons@Fairfield with permission from the rightsholder(s) and is protected by copyright and/or related rights. You are free to use this item in any way that is permitted by the copyright and related rights legislation that applies to your use. For other uses, you need to obtain permission from the rights-holder(s) directly, unless additional rights are indicated by a Creative Commons license in the record and/or on the work itself. For more information, please contact digitalcommons@fairfield.edu. 


\title{
REGIONAL GENETIC STRUCTURE IN THE MAGELLANIC PENGUIN (SPHENISCUS MAGELLANICUS) SUGGESTS METAPOPULATION DYNAMICS
}

\author{
Juan L. Bouzat, ${ }^{1,3}$ Brian G. Walker, ${ }^{2,4}$ and P. Dee Boersma ${ }^{2}$ \\ ${ }^{1}$ Department of Biological Sciences, Bowling Green State University, Life Sciences Building, Bowling Green, Ohio 43403, USA; and \\ ${ }^{2}$ Department of Biology, University of Washington, Seattle, Washington 98195, USA
}

\begin{abstract}
AвSTRACT.-Using microsatellite markers and mitochondrial DNA (mtDNA) sequences (cytochrome oxidase 1 gene), we estimated levels of genetic structuring among nine Magellanic Penguin (Spheniscus magellanicus) colonies distributed throughout three major reproductive regions of the South Atlantic Ocean. Overall, breeding colonies showed relatively high levels of genetic diversity at both nuclear and mtDNA markers (mean heteorzygosity: $H_{\mathrm{e}}=0.598$; mean allelic diversity: $A=7.11$; mtDNA haplotype diversity: $h=0.812$ ). A hierarchical analysis of molecular variance based on microsatellite data showed limited genetic structuring of breeding colonies, with $99 \%$ of the variation explained by differences among individuals and $0.7-1.0 \%$ attributed to differences among the three regions. The mtDNA analysis revealed higher levels of genetic structuring, with $3.43 \%$ of the variation explained by regions and $2.24 \%$ explained by colonies within the regions. Furthermore, a Mantel test revealed a significant association between geographic and genetic distances among colonies. The limited genetic structuring we detected is likely a result of (1) population intermixing through natal dispersal and (2) the large effective sizes of the reproductive colonies, both of which prevent genetic differentiation at neutral markers, balanced with (3) the regional association of breeding colonies to distinct feeding grounds and (4) a recent expansion of the population. Our results suggest that the demographic dynamics of breeding colonies of Magellanic Penguins may be framed under a metapopulation model, in which colonies with large numbers of breeding pairs could be considered "source" populations for maintaining the overall abundance of this species in the Atlantic Ocean. Received 9 July 2007, accepted 11 November 2008.
\end{abstract}

Key words: conservation genetics, genetic structure, Magellanic Penguin, metapopulation, population genetics, Spheniscus magellanicus.

\section{La Estructura Genética Regional en el Pingüino Spheniscus magellanicus Sugiere Dinámicas Metapoblacionales}

RESUMEN.-Utilizando marcadores microsatelitales y secuencias de ADN mitocondrial (ADNmt; gen citocromo oxidasa 1), estimamos los niveles de estructuración genética entre nueve colonias del pingüino Spheniscus magellanicus, que se distribuyen a través de tres regiones reproductivas principales en el Océano Atlántico del Sur. En general, las colonias reproductivas mostraron niveles altos de diversidad genética tanto a nivel de los marcadores nucleares como de los de ADNmt (heterocigocidad media: $H_{\mathrm{e}}=0.598$; diversidad alélica media: $A=7.11$; diversidad de haplotipos de ADNmt: $h=0.812$ ). Un análisis jerárquico de varianza molecular basado en los datos de microsatélites mostró una baja estructuración de las colonias reproductivas, con el 99\% de la varianza explicada por diferencias entre individuos y 0.7-1.0\% atribuible a diferencias entre las tres regiones. El análisis de ADNmt reveló niveles de estructuración mayor, con un 3.43\% de la variación explicada por las regiones y 2.24\% explicada por las colonias dentro de las regiones. Además, una prueba de Mantel reveló una asociación significativa entre las distancias genéticas y geográficas entre las colonias. La escasa estructuración genética que detectamos probablemente es el resultado de: (1) la mezcla entre poblaciones por dispersión natal y (2) el gran tamaño efectivo de las colonias reproductivas, dos factores que previenen la diferenciación genética en marcadores neutros, acoplado a (3) la asociación regional de las colonias reproductivas con diferentes áreas de forrajeo y (4) a una expansión reciente de la población. Nuestros resultados sugieren que la dinámica demográfica de las colonias reproductivas de $S$. magellanicus puede estar enmarcada en un modelo metapoblacional, donde las colonias con un gran número de parejas reproductivas podrían ser consideradas como poblaciones "fuente" para mantener la abundancia total de esta especie en el Océano Atlántico.

${ }^{3}$ E-mail: jbouzat@bgnet.bgsu.edu

${ }^{4}$ Present address: Department of Biology, Fairfield University, Fairfield, Connecticut 06824, USA.

The Auk, Vol. 126, Number 2, pages 326-334. ISSN 0004-8038, electronic ISSN 1938-4254. @ 2009 by The American Ornithologists' Union. All rights reserved. Please direct all requests for permission to photocopy or reproduce article content through the University of California Press's Rights and Permissions website, http://www.ucpressjournals. com/reprintInfo.asp. DOI: 10.1525/auk.2009.07122 
ONE OF THE challenges of conservation biology is to identify natural populations that may be considered important conservation units because of their genetic distinctiveness, their local adaptation, and their potential demographic contribution to the overall persistence of species (Crandall et al. 2000, Fraser and Bernatchez 2001, Green 2005). Characterization of conservation units is critical in managing and protecting threatened populations and in designing appropriate biological reserves to preserve biodiversity. For example, Marine Protected Areas (i.e., fixed areas that exclude human activities) have been proposed to protect species within small geographic ranges, whereas Marine Zoning may be needed to protect wide-ranging species with less predictable patterns of habitat use (Boersma and Parrish 1999, Hyrenbach et al. 2000). Understanding the spatial and temporal dynamics of individual populations within the species distribution is, therefore, essential for designing a meaningful conservation strategy.

Over the past few decades, advances in molecular genetic techniques and population genetics have played an essential role in conservation science (DeSalle and Amato 2004). Population genetic and phylogenetic studies have proved useful in determining levels of genetic diversity and population structure (e.g., Bouzat et al. 1998a, Bouzat 2001), estimating current gene flow, historical connectivity among populations (Johnson et al. 2007), and effective population sizes (Frankham 1996), identifying genetically distinct units of conservation concern (Moritz 1994, Moritz et al. 1994), and inferring past demographic processes such as bottlenecks and population expansions (Bouzat et al. 1998b, Ross et al. 2006).

Seabirds, and penguins in particular, represent a challenge to conservation scientists because of their characteristic reproductive biology and population demography. Many of these species are highly phylopatric, with individuals mating and reproducing in local breeding colonies in relatively isolated areas, forming reproductive groups that may be demographically and genetically independent (Williams 1995). In some cases (e.g., Galapagos Penguin [Spheniscus mendiculus]), the species has a restricted geographic distribution, which may increase the probability of population bottlenecks (Akst et al. 2002). On the other hand, other penguins are relatively abundant and have wide-ranging distributions with considerable genetic mixing (Roeder et al. 2001, Overeem et al. 2008). Therefore, the genetic characterization of avian breeding colonies is useful for identifying potential units of conservation concern.

We examined the genetic structure of breeding colonies of the Magellanic Penguin (S. magellanicus) from Patagonia and the Malvinas-Falkland Islands in the South Atlantic Ocean. Magellanic Penguins are colonial-breeding seabirds whose range extends from $42^{\circ} \mathrm{S}$ on the eastern coast of South America, down around Cape Horn and north to $29^{\circ} \mathrm{S}$ on the Pacific coast, and includes the Malvinas-Falklands (Williams 1995). This species is estimated to have $\sim 1.5$ million breeding pairs, with $>650,000$ pairs breeding along the Atlantic coast of Argentina and thousands of breeding pairs throughout the Malvinas-Falkland archipelago (Gandini et al.1996). Although the species is still abundant, there are significant threats from the direct effects of oil pollution and from competition for common resources by commercial fisheries, which affect ocean productivity (Gandini et al. 1994; Boersma 1997, 2008).
The dynamics of individual reproductive colonies in the Magellanic Penguin can be framed under the metapopulation concept (i.e., a group of interacting populations; Hanski and Gilpin 1997, Hanski and Gaggiotti 2004). This concept is based on the notion that species are spatially structured in local breeding populations that inhabit areas of differential productivity, which are interconnected through migration (Levins 1969). The original concept was later expanded to include assumptions of population turnover, local population extinctions, and colonization events (Hanski and Gilpin 1997). Under the metapopulation framework, demographic processes such as population growth and recruitment may be directly linked to the level of connectivity among reproductive colonies (e.g., through natal dispersal and migration leading to gene flow). The metapopulation concept is particularly relevant with regard to colonial seabirds, because breeding colonies likely differ in their abundance and fitness as a result of differences in habitat suitability for nesting sites and resource availability (e.g., location in relation to foraging areas). In addition, there is historical evidence of establishment and extinction of individual colonies, which may lead to population-colony turnover through extinction and recolonization events.

Few studies have concentrated on the population genetics of penguins. Since the early reports by Meredith and Sin (1988) on biochemical polymorphisms in the Little Blue Penguin (Eudyptula minor), most recent studies have focused on the characterization of DNA markers (e.g., Ritchie and Lambert 2000, Bertellotti et al. 2002, Roeder et al. 2002, Schlosseret al. 2003, Slack et al. 2003), species comparisons (e.g., Thumser and Karron 1994, Tsuda et al. 2001, Akst et al. 2002, Banks et al. 2006, Bollmer et al. 2007), and temporal changes in allele frequencies (e.g., Lambert et al. 2002, Shepherd et al. 2005). To our knowledge, the only large-scale population genetic study on penguins focused on the Adélie Penguin (Pygoscelis adeliae; Roeder et al. 2001). This study revealed a lack of genetic differentiation among colonies around Antarctica, despite this species' wide geographic distribution and substantial levels of genetic variation. Population genetic studies on other penguin species are, therefore, necessary for evaluating whether this lack of genetic structuring is restricted to the Adélie Penguin or is a common feature of the characteristic colonial reproductive structure of penguins.

Using microsatellite markers and mitochondrial DNA (mtDNA) sequences, we evaluated levels of genetic diversity among and within three major Magellanic Penguin breeding areas in the South Atlantic Ocean, estimating levels of genetic structuring among Northern and Southern Patagonia and Malvinas-Falkland breeding colonies. Our results revealed limited but significant genetic structure at the regional level and suggest that a metapopulation genetic framework may be useful in designing conservation strategies for penguins and other colonial seabirds with wide-range geographic distributions.

\section{Methods}

Studied populations and sampling.-The present study is based on a genetic analysis of nine Magellanic Penguin colonies located throughout a large part of the geographic range of this species in the South Atlantic Ocean (Fig. 1). Individual colonies were grouped in three major regions based on patterns of oceanographic 


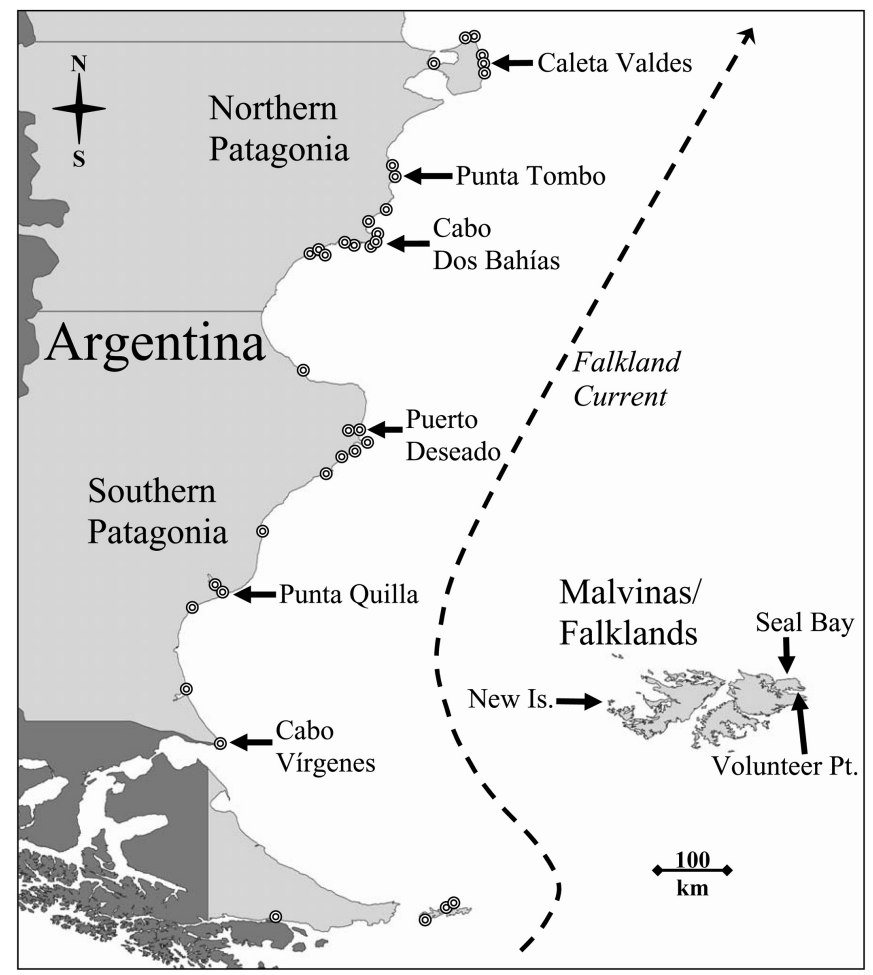

Fig. 1. Distribution of Magellanic Penguin breeding colonies in the South Atlantic Ocean. Arrows indicate location of breeding colonies used for the genetic analysis in the present study. Colonies have been grouped in three major reproductive areas including Northern Patagonia, Southern Patagonia, and the Malvinas-Falkland Islands.

productivity (Boersma et al. 2009), including the Northern Patagonia region (Caleta Valdés: $42^{\circ} 28^{\prime} \mathrm{S}, 63^{\circ} 21^{\prime} \mathrm{W}$; Punta Tombo: $44^{\circ} 02^{\prime} \mathrm{S}, 65^{\circ} 11^{\prime} \mathrm{W}$; and Cabo Dos Bahías: $\left.44^{\circ} 54^{\prime} \mathrm{S}, 65^{\circ} 32^{\prime} \mathrm{W}\right)$, the Southern Patagonia region (Puerto Deseado: $47^{\circ} 45^{\prime} \mathrm{S}, 65^{\circ} 56^{\prime} \mathrm{W}$; Punta Quilla: $50^{\circ} 07^{\prime} \mathrm{S}, 68^{\circ} 23^{\prime} \mathrm{W}$; and Cabo Vírgenes: $52^{\circ} 20^{\prime} \mathrm{S}$, $68^{\circ} 21^{\prime} \mathrm{W}$ ), and the Malvinas-Falkland Islands (New Island: $51^{\circ} 42^{\prime} \mathrm{S}, 61^{\circ} 16^{\prime} \mathrm{W}$; Volunteer Point: $51^{\circ} 28^{\prime} \mathrm{S}, 57^{\circ} 50^{\prime} \mathrm{W}$; and Seal Bay: $\left.51^{\circ} 24^{\prime} \mathrm{S}, 58^{\circ} 02^{\prime} \mathrm{W}\right)$. Our division of areas seems reasonable, given that oceanographic productivity is higher in the southern than in the northern colonies (Boersma et al. 2009). In addition, Magellanic Penguins in the Malvinas-Falkland Islands are several hundred kilometers from the mainland and forage close to their colonies during the breeding season (Boersma et al. 2002).

Blood samples for genetic analyses were collected from breeding adults in their nests during the breeding seasons of 1998-2001. Samples were collected from each colony from at least two areas separated by $\geq 30 \mathrm{~m}$. No recently hatched chicks or juvenile blood samples were analyzed. Approximately 100$200 \mu \mathrm{L}$ of blood were collected by puncture of the brachial vein and stored in $1 \mathrm{~mL}$ of Queen's lysis buffer (0.01 M Tris, $0.01 \mathrm{M}$ $\mathrm{Na}_{2}$ EDTA, $0.01 \mathrm{M} \mathrm{NaCl}$, and $1 \% \mathrm{n}$-lauroylsarcosine; Seutin et al. 1991) until further analysis. DNA for genetic analysis was isolated using standard phenol-chloroform extraction protocols followed by ethanol precipitation and DNA resuspension in sterile water (Sambrook et al. 1989).
Microsatellite analysis.-The microsatellite analysis was based on the amplification and typing of four microsatellite loci (microsatellites B3, G2, H2, and M1) designed and tested in Magellanic Penguins and Humboldt Penguins (S. humboldti) (Akst et al. 2002). Polymerase chain reaction (PCR) amplification and genotyping procedures were performed using fluorescently labeled primers (Operon Technologies, Alameda, California) for detection in a MegaBACE 1000 DNA analysis system (Amersham Biosciences, Piscataway, New Jersey). Fragment analysis was performed using Amerhsam's Genetic Profiler software suite. Sample sizes for the microsatellite analysis varied from 11 for Seal Bay, Malvinas-Falkland, to 40 for Punta Tombo, Argentina (Table 1). Simulations in the program POWSIM, version 4.0 (Ryman and Palm 2006), demonstrated that the levels of polymorphism detected in the four loci analyzed provided enough power (>95\%) to detect $1 \%$ genetic differentiation among colonies (see below).

Standard estimates of genetic variability (both observed $\left[H_{\mathrm{o}}\right]$ and expected $\left[H_{\mathrm{e}}\right]$ heterozygosities, and allelic diversity $[A]$ ) were quantified for each studied colony-population using the program ARLEQUIN (Schneider et al. 2000). We used ARLEQUIN to test for linkage disequilibrium and Hardy-Weinberg expectations. Linkage disequilibrium was tested using a likelihood-ratio test, the empirical distribution generated by permutations (Slatkin and Excoffier 1996). Deviations from Hardy-Weinberg equilibrium were tested as deviation of the Wright's $F_{\text {IS }}$ index (Wright 1978) from zero. Hardy-Weinberg expectations were tested for each locus, for all loci, and for each population using randomization procedures with 1,000 permutations (Guo and Thompson 1992).

Overall levels of genetic differentiation among regions (Northern Patagonia, Southern Patagonia, and Malvinas-Falkland Islands) and among colonies within regions were estimated using a hierarchical analysis of molecular variance (AMOVA; Excoffier et al. 1992) and computing the Wright's $F_{\mathrm{ST}}$ statistics (Weir and Cockerham 1984) and the corresponding $R_{\mathrm{ST}}$ (Slatkin 1995) designed for microsatellite markers. In addition, we computed colony pairwise $F_{\mathrm{ST}}$ and $R_{\mathrm{ST}}$ to assess genetic differentiation between individual colonies. In both cases, the statistical significance of the estimates was calculated using permutation procedures, with 10,000 and 1,000 permutations for the overall and pairwise estimates, respectively.

We used POWSIM to assess the statistical power and alpha error for testing the null hypothesis of genetic homogeneity under a classical Wright-Fisher model without migration or mutation. The simulation-based POWSIM estimates statistical power under different combinations of number of samples, sample sizes, number of loci, alleles, and allele frequencies for a specified degree of differentiation (Ryman and Palm 2006, Ryman et al. 2006). Simulations in POWSIM were performed assuming a base population with the average observed allele frequencies for the four microsatellite loci used, divided into nine populations (representing the nine sampled colonies) with the same sample sizes used in the present study. We performed two sets of simulations to test statistical power and alpha error for detecting $1 \%$ genetic differentiation $\left(F_{\mathrm{ST}}=0.01\right)$ reached through either 40 generations of effective sizes $N_{\mathrm{e}}=2,000$ for each colony or 100 generations of $N_{\mathrm{e}}=5,000$.

In addition to the hierarchical AMOVA, we also used ARLEQUIN to perform individual genotype assignment tests, estimating the log-likelihood of each individual multilocus genotype 
TABLE 1. Genetic diversity estimates (microsatellites and mtDNA cytochrome oxidase; $H_{\mathrm{o}}=$ observed heterozygosity; $H_{\mathrm{e}}=$ expected heterozygosity) for nine breeding colonies of Magellanic Penguins from Patagonia and the Malvinas-Falkland Islands.

\begin{tabular}{|c|c|c|c|c|c|c|c|c|}
\hline \multirow[b]{2}{*}{ Population } & \multirow[b]{2}{*}{$\begin{array}{l}\text { Sample } \\
\text { size } \\
\text { (micro/ } \\
\text { mtDNA) }\end{array}$} & \multicolumn{4}{|c|}{ Microsatellite DNA (four loci) } & \multicolumn{3}{|c|}{ mtDNA CO1 gene } \\
\hline & & $\begin{array}{l}\text { Mean } \\
\text { number } \\
\text { of alleles } \\
\text { locus }^{-1}\end{array}$ & $H_{\mathrm{o}} \pm \mathrm{SD}$ & $H_{\mathrm{e}} \pm \mathrm{SD}$ & $F_{\mathrm{IS}}$ & $\begin{array}{l}\text { Number of } \\
\text { haplotypes }\end{array}$ & $\begin{array}{c}\text { Haplotype } \\
\text { diversity } \\
(h \pm S D)\end{array}$ & $\begin{array}{l}\text { Nucleotide } \\
\text { diveristy } \\
(\pi \pm S D)\end{array}$ \\
\hline \multicolumn{9}{|l|}{ Northern Patagonia } \\
\hline Caleta Valdes & $26 / 10$ & 7.25 & $0.566 \pm 0.245$ & $0.607 \pm 0.230$ & 0.057 & 4 & $0.533 \pm 0.180$ & $0.004 \pm 0.002$ \\
\hline Punta Tombo & $40 / 9$ & 8.75 & $0.594 \pm 0.234$ & $0.617 \pm 0.216$ & -0.095 & 5 & $0.722 \pm 0.159$ & $0.005 \pm 0.002$ \\
\hline Cabo Dos Bahias & $29 / 10$ & 7.50 & $0.631 \pm 0.202$ & $0.624 \pm 0.212$ & 0.021 & 9 & $0.978 \pm 0.054$ & $0.005 \pm 0.001$ \\
\hline \multicolumn{9}{|l|}{ Southern Patagonia } \\
\hline Puerto Deseado & $29 / 10$ & 7.75 & $0.560 \pm 0.288$ & $0.572 \pm 0.271$ & 0.015 & 5 & $0.667 \pm 0.163$ & $0.003 \pm 0.001$ \\
\hline Punta Quilla & $23 / 9$ & 6.75 & $0.611 \pm 0.179$ & $0.589 \pm 0.210$ & -0.047 & 6 & $0.889 \pm 0.091$ & $0.006 \pm 0.002$ \\
\hline Cabo Virgenes & $25 / 10$ & 7.25 & $0.633 \pm 0.232$ & $0.600 \pm 0.257$ & 0.039 & 8 & $0.933 \pm 0.077$ & $0.003 \pm 0.001$ \\
\hline \multicolumn{9}{|l|}{$\begin{array}{l}\text { Malvinas-Falkland } \\
\text { Islands }\end{array}$} \\
\hline New Island & $30 / 10$ & 7.75 & $0.616 \pm 0.170$ & $0.645 \pm 0.228$ & -0.037 & 5 & $0.756 \pm 0.130$ & $0.001 \pm 0.000$ \\
\hline Volunteer Point & $18 / 9$ & 6.00 & $0.555 \pm 0.187$ & $0.570 \pm 0.173$ & 0.061 & 7 & $0.917 \pm 0.008$ & $0.003 \pm 0.000$ \\
\hline Seal Bay & $11 / 10$ & 5.00 & $0.523 \pm 0.226$ & $0.555 \pm 0.222$ & -0.139 & 7 & $0.911 \pm 0.077$ & $0.004 \pm 0.001$ \\
\hline Mean & & 7.11 & $0.588 \pm 0.038$ & $0.598 \pm 0.029$ & -0.014 & 6.2 & $0.812 \pm 0.150$ & $0.004 \pm 0.001$ \\
\hline All samples & $231 / 87$ & 11.50 & $0.592 \pm 0.212$ & $0.609 \pm 0.225$ & 0.019 & 19 & $0.639 \pm 0.050$ & $0.003 \pm 0.001$ \\
\hline
\end{tabular}

in each population sample (Schneider et al. 2000). Furthermore, we performed a Mantel test to estimate correlations between geographic and genetic distances among colonies (Smouse et al.1986). Statistical significance of Mantel-test correlation coefficients was estimated through permutation procedures $(10,000$ permutations; Schneider et al. 2000).

Mitochondrial DNA analysis.-The mtDNA analysis was based on the amplification and sequencing of a DNA fragment of $\sim 710$ base pairs (bp) of the mitochondrial gene cytochrome oxidase 1 (CO1). Amplifications were performed in $25-\mu \mathrm{L}$ reactions $\left(1 \mathrm{mM} \mathrm{MgCl}_{2}, 80 \mu \mathrm{m}\right.$ dNTPs, $0.2 \mu \mathrm{m}$ of each primer, and $1 \mathrm{U}$ of Taq polymerase) using primers EM5287 (5'-CACATCAATGAGCTTGCAACTC-3') and CO1R722 (5'-TAAACTTCAGGGTGACCAAAAAATYA-3'). Amplification profiles included 35 cycles of $30 \mathrm{~s}$ at $94^{\circ} \mathrm{C}, 30 \mathrm{~s}$ at $52^{\circ} \mathrm{C}$, and $1 \mathrm{~min}$ at $72^{\circ} \mathrm{C}$, followed by an extension step of $5 \mathrm{~min}$ at $72^{\circ} \mathrm{C}$. The PCR products were sequenced directly on an ABI 377 automated DNA sequencer using the BigDye Terminator chemistry (Applied Biosystems, Foster City, California) and standard protocols provided by the manufacturer. $\mathrm{CO} 1$ sequences were obtained from a total of 87 individual samples, including 9-10 samples from each population (Table 1). Sequences were visually inspected and aligned using BIOEDIT (Hall 1999) and trimmed to a fragment of $698 \mathrm{bp}$ for further analyses.

Standard measures of mtDNA diversity (haplotype diversity $[h]$ and nucleotide diversity $[P i])$ and corresponding standard deviations were obtained using the program DNASP (Rozas et al. 2003). A hierarchical AMOVA based on pairwise differences between haplotypes was performed using ARLEQUIN. The fixation indices $F_{\mathrm{CT}}, F_{\mathrm{SC}}$, and $F_{\mathrm{ST}}$ were computed to assess levels of variation among regions, among populations within regions, and within populations, respectively. Similarly, the statistical significance of estimates was calculated using permutation procedures, with 10,000 and 1,000 permutations for the overall and pairwise estimates, respectively. A Mantel test was also performed to assess the correlation between geographic distances and genetic distances based on mtDNA sequences.

\section{Results}

Microsatellite analysis.-The analysis of six Magellanic Penguin breeding colonies on the Patagonian shore of the South Atlantic Ocean and three in the Malvinas-Falkland archipelago revealed relatively high levels of genetic diversity (Table 1). With the exception of microsatellite locus $\mathrm{H} 2$, which showed three alleles, the other loci were highly polymorphic, with 9, 9, and 25 alleles for microsatellites B3, G2, and M1, respectively. Average ( \pm SD) allelic diversity per reproductive colony was $7.11 \pm 1.09$ (range: $5.00-$ 8.75 ), whereas the average observed and expected heterozygosity were $0.588 \pm 0.038$ and $0.598 \pm 0.029$, respectively (Table 1 ). Most alleles (41 of 46) were shared by two or more colonies. Only five alleles represented unique alleles identified in the reproductive colonies of Punta Tombo ( 2 alleles), Cabo Dos Bahías (1 allele), Cabo Vírgenes (1 allele), and New Island (1 allele).

All loci were under linkage disequilibrium when data from all breeding colonies were combined $(P>0.05)$. When each colony was analyzed separately, only 4 of the 54 colony-locus combinations showed significant linkage with $P$ values $<0.05$. Overall, allele frequencies at each reproductive colony did not differ from those expected under Hardy-Weinberg equilibrium. In all cases, population-specific $F_{\text {IS }}$ values were not significantly different from zero $(P>0.139$; Table 1$)$. When Hardy-Weinberg tests were performed for each individual locus in each population, only 2 of 36 tests showed significant deviations from Hardy-Weinberg expectations $(P<0.05)$, with one test revealing excess and the other deficiency of heterozygote genotypes. 
TABLE 2. Hierarchical analysis of molecular variance (AMOVA) based on microsatellite DNA markers (weighted averages of $F_{\mathrm{ST}}$ and $R_{\mathrm{ST}}$ distances) and cytochrome oxidase mtDNA sequences (haplotype pairwise differences).

\begin{tabular}{|c|c|c|c|c|c|c|}
\hline \multirow[b]{3}{*}{ Source of variation } & \multicolumn{4}{|c|}{ Microsatellites AMOVA } & \multirow{2}{*}{\multicolumn{2}{|c|}{$\begin{array}{c}\text { mtDNA AMOVA } \\
\text { Pairwise differences }\end{array}$}} \\
\hline & \multicolumn{2}{|c|}{ F-statistics } & \multicolumn{2}{|c|}{$R$-statistics } & & \\
\hline & $\begin{array}{c}\text { Variance } \\
\text { components }\end{array}$ & $\begin{array}{l}\text { Percentage } \\
\text { variation }\end{array}$ & $\begin{array}{c}\text { Variance } \\
\text { components }\end{array}$ & $\begin{array}{l}\text { Percentage } \\
\text { variation }\end{array}$ & $\begin{array}{c}\text { Variance } \\
\text { components }\end{array}$ & $\begin{array}{c}\text { Percentage } \\
\text { variation }\end{array}$ \\
\hline Among regions & 0.009 & $0.752 *$ & 1.505 & $1.011^{* *}$ & 0.122 & $3.43^{* *}$ \\
\hline Among colonies within regions & 0.004 & 0.354 & -0.651 & -0.437 & 0.079 & $2.24^{* *}$ \\
\hline Within colonies & 1.208 & $98.894^{* *}$ & 147.981 & 99.426 & 3.349 & $94.33^{* *}$ \\
\hline Total & 1.221 & 100 & 148.835 & 100 & 3.550 & 100 \\
\hline
\end{tabular}

*Marginally significant $(P=0.054)$.

**Significant $(P<0.05)$.

An AMOVA averaged over the four loci and using $F_{\mathrm{ST}}$ revealed minimal genetic structuring of breeding colonies, with 98.9\% of the variation explained by differences among individuals within reproductive colonies $\left(F_{\mathrm{ST}}=0.011, P=0.005\right)$. Only $0.75 \%$ of the observed variance was explained by differences among Northern Patagonia, Southern Patagonia, and MalvinasFalkland Islands (Table 2). The genetic differentiation among regions resulted in an overall $F_{\mathrm{CT}}=0.007$, which was marginally significant $(P=0.054)$. When using the microsatellite-based distance $R_{\mathrm{ST}}$ for the AMOVA, the percentage of variation among regions increased slightly to $1.05 \%$ and became significant $\left(R_{\mathrm{CT}}=\right.$ $0.010, P=0.048)$, whereas variation within colonies was nonsignificant $\left(R_{\mathrm{ST}}=0.006\right.$; Table 2$)$. In both cases, using either $F_{\mathrm{ST}}$ or $R_{\mathrm{ST}}$, differences among colonies within regions $\left(F_{\mathrm{SC}}=0.004\right.$; $\left.R_{\mathrm{SC}}=-0.004\right)$ did not show significant variation $(P>0.149$; Table 2). Colony pairwise $F_{\mathrm{ST}}$ revealed, however, significant differences for 6 of the 36 pairwise colony combinations $(P<0.05)$. As expected, significant genetic differences were found between reproductive colonies from different regions, with four significant $F_{\mathrm{ST}}$ values involving colonies from the Malvinas-Falkland Islands, two from Northern Patagonia, and one from Southern Patagonia. Simulations in POWSIM revealed significant power for detecting genetic differentiation at levels of $1 \%\left(F_{\mathrm{ST}}=0.01\right)$. Simulations assuming uniform effective sizes of 2,000 and 5,000 for each colony over 40 and 100 generations, respectively, resulted in $>95 \%$ power. In both cases, the alpha error remained below the expected $\alpha=0.05$.

To further evaluate this subtle population-genetic structure, we performed assignment tests to individual breeding colonies. Likelihood estimates of individual genotypes showed low proportions of correct assignments to individual colonies, with only an average of 49.1\% (range: 30.4-66.7\%) individuals assigned correctly to their corresponding colonies. When the three regions were considered as population units, the average percentage of correct assignments remained low but increased to $63 \%$.

The correlations between geographic and genetic distances based on $F_{\mathrm{ST}}$ and $R_{\mathrm{ST}}$ estimates were not significant (Mantel test based on $F_{\mathrm{ST}}$ distances: $r=0.207, P=0.098$; Mantel test based on $R_{\mathrm{ST}}$ distances: $r=0.218, P=0.093$ ). This was expected, given that the AMOVA based on $F_{\mathrm{ST}}$ distances did not reveal significant genetic structure at the regional level and that the AMOVA based on $R_{\mathrm{ST}}$ distances showed only limited genetic structuring (Table 2).
Mitochondrial DNA analysis.-Analysis of the 698-bp fragment of the CO1 mtDNA gene from 87 individual Magellanic Penguins resulted in 19 unique haplotypes (GenBank accession numbers: FJ407094-FJ407180). Comparisons of sequences revealed a total of 34 variable sites, with an average $( \pm$ SD) of $10.11 \pm 3.06$ substitutions per site and $2.52 \pm 0.89$ nucleotide differences per breeding colony (Table 1$)$. On average, breeding colonies had $6.2 \pm 1.6$ haplotypes, with a mean haplotype and nucleotide diversity of $0.812 \pm 0.150$ and $0.004 \pm 0.001$, respectively (Table 1).

Consistent with the microsatellite analysis, the AMOVA also revealed that most of the variation $(94.33 \%)$ was explained by differences among individuals within reproductive colonies $\left(F_{\mathrm{ST}}=0.057\right.$, $P<0.001$; Table 2). However, the mtDNA analysis revealed higher proportions of genetic variation among the three breeding regions (i.e., Northern Patagonia, Southern Patagonia, and MalvinasFalkland Islands) as well as among colonies within regions. Overall, $3.43 \%$ of the variation was explained by differences among regions $\left(F_{\mathrm{CT}}=0.034, P<0.024\right)$, whereas $2.24 \%$ was explained by differences among colonies within regions $\left(F_{\mathrm{SC}}=0.023, P<0.025\right.$; Table 2). Colony pairwise $F_{\mathrm{ST}}$ revealed significant differences for 15 of the 36 pairwise colony combinations $(P<0.05)$. As with the microsatellite analysis, most significant genetic differences (13 of 15 ) were found between reproductive colonies from different regions, whereas the other two significant $F_{\mathrm{ST}}$ values resulted from colonies within the Malvinas-Falkland Islands and the Southern Patagonia regions. The Mantel test revealed a significant correlation between geographic and genetic distances among colonies (Mantel test $r=0.453, P=0.008$ ), indicating that breeding colonies became more genetically differentiated as the distance between colonies increased.

\section{Discussion}

Our results showed that breeding colonies of Magellanic Penguins along the Atlantic coast of Patagonia and the Malvinas-Falkland Islands have relatively high levels of genetic variation and limited genetic structuring. The microsatellite analysis revealed that breeding colonies have high levels of genetic variability in terms of both heterozygosity and allelic diversity (Table 1), which suggests that these colonies have not been subjected to small population processes (e.g., associated with past bottlenecks). This is consistent with the idea that Magellanic Penguins may have recently 
expanded their breeding range to the north (Boersma et al. 1990, Boersma 2008). Genotype frequencies did not differ from those expected under Hardy-Weinberg equilibrium, which is also consistent with the historically large effective population size of this species ( $>100,000$ breeding pairs in some colonies).

The hierarchical AMOVA indicated that $98-99 \%$ of the variation detected at the nuclear markers can be explained by differences among individuals within colonies, whereas $0.7-1.0 \%$ can be attributed to differences among the three major reproductive areas defined as Northern Patagonia, Southern Patagonia, and the Malvinas-Falkland Islands (Fig. 1). This subtle genetic differentiation among major breeding regions, which resulted in $F_{\mathrm{CT}}$ and $R_{\mathrm{CT}}$ values of 0.007 and 0.010 , respectively, may be associated with the relatively large geographic distances among these regions and the use of independent foraging areas by some of these colonies (Boersma et al. 2002). Interestingly, the genetic structuring mirrors the patterns of oceanographic productivity between the northern and southern colonies in Patagonia (Boersma et al. 2009). The limited genetic structuring was also reflected in the low proportion of correct genotype assignments to either individual colonies (49.1\%) or the three reproductive regions (63\%).

We cannot discard the possibility that greater levels of genetic structuring would be detected if we increased the number of microsatellite loci analyzed. Despite the relatively small number of microsatellite loci used in the present study, POWSIM simulations based on average effective sizes of 2,000 and 5,000 individuals revealed that, with the sampling sizes used and the observed levels of polymorphism and allele frequencies, we had high statistical power $(>95 \%)$ and low alpha error $(<0.05)$ for detecting genetic differentiation at the $1 \%$ level $\left(F_{\mathrm{ST}}=0.01\right)$. The statistical power, however, decreased considerably for detecting lower levels of genetic differentiation (e.g., for $F_{\mathrm{ST}}<0.005$ ), so we surveyed levels of genetic diversity at the $\mathrm{CO} 1$ gene to evaluate whether trends similar to those detected with microsatellites were observed at an independent mtDNA marker.

Results from the mtDNA analysis confirmed the limited levels of genetic structuring detected by nuclear DNA markers. However, the AMOVA based on the mtDNA sequences revealed a significantly higher proportion of genetic variation at the regional level (3.4\% vs. 1.0\% detected by microsatellites) and relatively low but significant levels of differentiation among colonies within regions (2.2\%). The increased level of genetic differentiation detected by the CO1 marker is consistent with the reduced effective size of the mitochondrial genome, which is one-fourth the effective size for diploid nuclear markers (Avise 2004). However, increased genetic differentiation in maternally inherited (e.g., mtDNA) as compared with biparentally inherited markers (e.g., microsatellites) could also indicate sex-biased dispersal, philopatry, and location of pair-bond formation in relation to breeding sites (see Scribner et al. 2001, Avise 2004). Although breeding pairs of Magellanic Penguins show high colony and pair-bond fidelity, information on dispersal is limited. Studies of banded juveniles suggest that penguins show some fidelity to the colonies where they hatched (Boersma 2008). However, most penguins do not lay eggs or find a mate until they are five to eight years old, which gives them opportunities for interbreeding with individuals from other colonies. Differences in spatial genetic variance between microsatellites and mtDNA could, therefore, indicate higher dispersal rates of males among colonies.

The regional genetic structuring of Magellanic Penguin colonies in the present study contrasts with the reports of Roeder et al. (2001) on the Adélie Penguin and Overeem et al. (2008) on the Little Blue Penguin. Roeder et al. (2001) found a lack of genetic differentiation among breeding colonies around the Antarctic continent, despite substantial levels of genetic variation. Because Adélie Penguins exhibit natal philopatry, the lack of genetic differentiation in this species was explained mainly as a result of an interaction between the large effective population sizes and relatively high migration rates through adult dispersal between colonies. Similarly, genetic homogeneity among Little Blue Penguin colonies was explained by historical or contemporary gene flow (Overeem et al. 2008).

Large effective population sizes may also play an important role in preventing genetic differentiation among relatively distant colonies of Magellanic Penguins. The Antarctic distribution of Adélie Penguins, whose range is mainly restricted to the rich ocean south of the Antarctic Circumpolar Current (Ainley 2002), may facilitate migration among colonies. By contrast, individual breeding colonies of Magellanic Penguins have restricted distributions driven by distinct oceanographic productivity patterns in the Pacific and Atlantic shores of South America and the Malvinas-Falkland Islands (Boersma et al. 2009). This may explain the significant genetic structuring observed at the regional level between breeding colonies associated with different feeding grounds, and the significant association between genetic and geographic distances among colonies revealed by the mtDNA-based Mantel test, which is consistent with a model of isolation-bydistance.

The limited genetic structuring in Magellanic Penguins suggests a relatively highly connected gene pool. This connectivity among colonies is likely the result of two major factors: (1) juvenile recruitment from different colonies and (2) a recent population expansion. Field data indicate that Magellanic Penguins show high breeding-site fidelity (breeding philopatry); in many cases, the same pair selects the same nesting site for their breeding lifespan (e.g., one pair stayed together in the same nest for 16 years; Boersma 2008). Population intermixing is, therefore, likely to be driven through population mixing of juveniles and young adults before breeding pairs are established. As previously mentioned, the differences in the magnitude of the spatial variance between mtDNA haplotypes and microsatellites reported here suggest the potential for sex-biased dispersal, which is common in migratory avian species (Ely and Scribner 1994, Scribner et al. 2001). Limited genetic structuring, particularly within regions, may also result from rapid population expansions during favorable periods (e.g., periods of high resource availability). This is consistent with historical evidence documenting a recent population expansion of the breeding range of the Magellanic Penguin farther north (Boersma 2008). For example, Punta Tombo, currently the largest colony for this species, with $\sim 200,000$ breeding pairs, was first colonized in the early 1920s, and the colony at the Caleta Valdes was settled in 1969 (Boersma et al. 1990). The limited time over which these expansions occurred (approximately $<10$ generations) certainly limits the probability of genetic differentiation taking place, particularly within reproductive regions. The lack of distinct 
phylogeographic patterns of mitochondrial CO1 sequences associated with the major reproductive regions (data not shown) is also consistent with the limited genetic structuring reported here.

Metapopulation dynamics of Magellanic Penguins.-The demographic dynamics we have described pose an important question regarding the characterization of potential conservation units in species with highly localized reproductive colonies but with wide distribution ranges associated with their feeding migrations during the non-reproductive seasons. The limited genetic structuring and large effective sizes suggest that individual colonies are not genetically independent and, thus, that preservation of genetic diversity may not be a major concern. However, this does not mean that all Magellanic Penguin colonies represent a single demographic unit. In fact, genetic differentiation at neutral markers is generally used to infer demographic independence (Moritz et al. 1994). In Magellanic Penguins, genetic structuring at the regional level is most likely driven by the association of breeding colonies with spatial patterns of oceanographic productivity that define distinct feeding grounds (Boersma 2008, Boersma et al. 2009).

Given the large differences in colony size, which varies from a few dozens to tens of thousands of breeding pairs, it is apparent that there is a differential demographic input of reproductive colonies, with some individual colonies contributing significantly large proportions to the annual recruitment of newborn individuals. These colonies could be considered "source" populations for the maintenance of less productive colonies or establishment of new colonies. Abundance data and morphological data suggest that ecological differences between colonies (e.g., associated with quality of nesting sites or location in relation to foraging grounds) affect the fitness of individual penguins (Stokes and Boersma 1998, 2000; Boersma et al. 2009). Overall reproductive success in penguins may, therefore, be directly associated with colony size and location, a hypothesis that should be further evaluated in future studies (see Hunt et al. 1986).

The complex demographic dynamics of the Magellanic Penguin-and of other seabird species with localized reproductive colonies and wide-ranging foraging grounds associated with patterns of ocean productivity-represent a challenge to conservation scientists. A metapopulation framework that takes into account the differential inputs of individual colonies and their interactions through natal dispersal and recruitment of breeding pairs may be necessary in designing proper management strategies for Magellanic Penguins and other seabird species with similar demographic dynamics.

\section{ACKNOWLEDGMENTS}

We thank V. Bingman, K. Scribner, and three anonymous reviewers for valuable comments on earlier versions of the manuscript, and P. Bentzen for the instruction and use of genotyping equipment. In addition, we thank the Wildlife Conservation Society, Exxon/Mobil Foundation, Pew Charitable Trust in partnership with the New England Aquarium, New Island Trust, Wadsworth Endowment, National Science Foundation (grant opp-9708594 to P.D.B.), and Friends of the Penguins for support. Sigma Xi provided support to B.G.W. A. Clark, K. Flynn, M. Hogg, L. Hood, M. Riley, and A. Van Buren helped us collect blood samples.

\section{Literature Cited}

Ainley, D. G. 2002. The Adélie Penguin: Bellwether of Climate Change. Columbia University Press, New York.

Akst, E. P., P. D. Boersma, And R. C. Fleischer. 2002. A comparison of genetic diversity between Galápagos Penguin and the Magellanic Penguin. Conservation Genetics 3:375-383.

AvisE, J. C. 2004. Molecular Markers, Natural History, and Evolution, 2nd ed. Sinauer Associates, Sunderland, Massachusetts.

Banks, J., A. Van Buren, Y. Cherel, And J. B. Whitfield. 2006. Genetic evidence for three species of rockhopper penguins, Eudyptes chrysocome. Polar Biology 30:61-67.

Bertellotti, M., J. L. Tella, J. A. Godoy, G. Blanco, M. G. Forero, J. A. Donázar, ANd O. Ceballos. 2002. Determining sex of Magellanic Penguins using molecular procedures and discriminant functions. Waterbirds 25:479-484.

Boersma, P. D. 1997. Magellanic Penguins decline in south Atlantic. Penguin Conservation 10:2-5.

Boersma, P. D. 2008. Penguins as marine sentinels. BioScience 58:597-607.

Boersma, P. D., AND J. K. PARrish. 1999. Limiting abuse: Marine protected areas, a limited solution. Ecological Economics 31:287-304.

Boersma, P. D., G. A. Rebstock, E. Frere, and S. E. Moore. 2009. Following the fish: Penguins and productivity in the South Atlantic. Ecological Monographs 79: in press.

Boersma, P. D., D. L. Stokes, and I. J. Strange. 2002. Applying ecology to conservation: Tracking breeding penguins at New Island South Reserve, Falkland Islands. Aquatic Conservation: Marine and Freshwater Ecosystems 12:63-74.

Boersma, P. D., D. L. Stokes, AND P. Yorio. 1990. Reproductive variability and historical change of Magellanic Penguins (Spheniscus magellanicus) at Punta Tombo, Argentina. Pages 15-43 in Biology of Penguins (L. Davis and J. Darby, Eds.). Macmillan, New York.

Bollmer, J. L., F. H. Vargas, and P. G. PArker. 2007. Low MHC variation in the endangered Galápagos Penguin (Spheniscus mendiculus). Immunogenetics 59:593-602.

BouzAT, J. L. 2001. The population genetic structure of the Greater Rhea (Rhea americana) in an agricultural landscape. Biological Conservation 99:277-284.

Bouzat, J. L., H. H. Cheng, H. A. Lewin, R. L. Westemeier, J. D. Brawn, AND K. N. Paige. 1998a. Genetic evaluation of a demographic bottleneck in the Greater Prairie Chicken. Conservation Biology 12:836-843.

Bouzat, J. L., H. A. Lewin, And K. N. Paige. 1998b. The ghost of genetic diversity past: Historical DNA analysis of the Greater Prairie Chicken. American Naturalist 152:1-6.

Crandall, K. A., O. R. P. Bininda-Emonds, G. M. Mace, and R. K. WAYNE. 2000. Considering evolutionary processes in conservation biology. Trends in Ecology and Evolution 15:290-295.

Desalle, R., And G. Amato. 2004. The expansion of conservation genetics. Nature Reviews Genetics 5:702-712.

Ely, C. R., And K. T. SCRibner. 1994. Genetic diversity in Arcticnesting geese: Implications for management and conservation. Transactions of the North American Wildlife and Natural Resources Conference 59:91-110.

Excoffier, L., P. E. Smouse, And J. M. Quattro. 1992. Analysis of molecular variance inferred from metric distances among DNA 
haplotypes: Application to human mitochondrial DNA restriction data. Genetics 131:479-491.

FRANKHAM, R. 1996. Relationship of genetic variation to population size in wildlife. Conservation Biology 10:1500-1508.

Fraser, D. J., And L. Bernatchez. 2001. Adaptive evolutionary conservation: Towards a unified concept for defining conservation units. Molecular Ecology 10:2741-2752.

Gandini, P., P. D. Boersma, E. Frere, M. Gandini, T. Holik, And V. Lichtschein. 1994. Magellanic Penguins (Spheniscus magellanicus) affected by chronic petroleum pollution along coast of Chubut, Argentina. Auk 111:20-27.

Gandini, P. A., E. Frere, ANd P. D. Boersma. 1996. Status and conservation of Magellanic Penguins (Spheniscus magellanicus) in Patagonia, Argentina. Bird Conservation International 6:307-316.

Green, D. M. 2005. Designatable units for status assessment of endangered species. Conservation Biology 19:1813-1820.

Guo, S. W., And E. A. Thompson. 1992. Performing the exact test of Hardy-Weinberg proportion for multiple alleles. Biometrics 48:361-372.

Hall, T. A. 1999. BioEdit: A user-friendly biological sequence alignment editor and analysis program for Windows 95/98/NT. Nucleic Acids Symposium Series 41:95-98.

Hanski, I. A., And O. E. Gaggiotti, Eds. 2004. Ecology, Genetics and Evolution of Metapopulations. Elsevier Academic Press, San Diego, California.

Hanski, I. A., And M. E. GiLPIn, EdS. 1997. Metapopulation Biology: Ecology, Genetics, and Evolution. Academic Press, San Diego, California.

Hunt, G. L., JR., Z. A. Eppley, And D. C. Schneider. 1986. Reproductive performance of seabirds: The importance of population and colony size. Auk 103:306-317.

Hyrenbach, K. D., K. A. Forney, and P. K. Dayton. 2000. Marine protected areas and ocean basin management. Aquatic Conservation of Marine Freshwater Ecosystems 10:437-458.

Johnson, J. A., P. O. Dunn, AND J. L. Bouzat. 2007. Effects of recent population bottlenecks on reconstructing the demographic history of prairie-chickens. Molecular Ecology 16:2203-2222.

Lambert, D. M., P. A. Ritchie, C. D. Millar, B. Holland, A. J. DRUMMOND, AND C. BARONI. 2002. Rates of evolution in ancient DNA from Adélie Penguins. Science 295:2270-2273.

LEVINS, R. 1969. Some demographic and genetic consequences of environmental heterogeneity for biological control. Bulletin of the Entomological Society of America 15:237-240.

Meredith, M. A. M., AND F. Y. T. Sin. 1988. Genetic variation of four populations of the Little Blue Penguin, Eudyptula minor. Heredity 60:69-76.

Moritz, C. 1994. Defining 'evolutionarily significant units' for conservation. Trends in Ecology and Evolution 9:373-375.

Moritz, C. C., S. Lavery, and R. Slade. 1994. Using allele frequency and phylogeny to define units for conservation and management. American Fisheries Society Symposium 17:249-262.

Overeem, R. L., A. J. Peucker, C. M. Austin, P. Dann, and C. P. BuRRIDGE. 2008. Contrasting genetic structuring between colonies of the world's smallest penguin, Eudyptula minor (Aves: Spheniscidae). Conservation Genetics 9:893-905.

Ritchie, P. A., And D. M. Lambert. 2000. A repeat complex in the mitochondrial control region of Adélie Penguins from Antartica. Genome 43:613-618.
Roeder, A. D., R. K. Marshall, A. J. Mitchelson, T. Visagathilagar, P. A. Ritchie, D. R. Love, T. J. Pakai, H. C. Mcpartlan, N. D. Murray, N. A. Robinson, and Others. 2001. Gene flow on the ice: Genetic differentiation among Adélie Penguin colonies around Antarctica. Molecular Ecology 10: 1645-1656.

Roeder, A. D., P. A. Ritchie, and D. M. Lambert. 2002. New DNA markers for penguins. Conservation Genetics 3:341-344.

Ross, J. D., A. D. Arndt, R. F. C. Smith, J. A. Johnson, And J. L. Bouzat. 2006. Re-examination of the historical range of the Greater Prairie Chicken using provenance data and DNA analysis of museum collections. Conservation Genetics 7:735-750.

Rozas, J., J. C. SÁnchez-Delbarrio, X. Messeguer, and R. RozAs. 2003. DnaSP, DNA polymorphism analyses by the coalescent and other methods. Bioinformatics 19:2496-2497.

Ryman, N., AND S. PALM. 2006. POWSIM: A computer program for assessing statistical power when testing for genetic differentiation. Molecular Ecology Notes 6:600-602.

Ryman, N., S. Palm, C. André, G. R. Carvalho, T. G. Dahlgren, P. E. Jorde, L. Laikre, L. C. Larsson, A. Palmé, and D. E. Ruzzante. 2006. Power for detecting genetic divergence: Differences between statistical methods and marker loci. Molecular Ecology 15:2031-2045.

SAmbrooK, J., E. F. FritsCh, AND T. Maniatis. 1989. Molecular Cloning: A Laboratory Manual, 2nd ed. Cold Spring Harbor Laboratory Press, Cold Spring Harbor, New York.

Schlosser, J. A., T. W. J. Garner, J. M. Dubach, and A. G. McelLigotT. 2003. Characterization of microsatellite loci in Humboldt Penguin (Spheniscus humboldti) and cross-amplification in other penguin species. Molecular Ecology Notes 3:62-64.

Schneider, S., D. Roessli, And L. Excoffier. 2000. ARLEQUIN: A Software for Population Genetic Data Analysis. University of Geneva, Geneva, Switzerland. [Online.] Available at lgb.unige.ch/ arlequin/.

Scribner, K. T., M. R. Petersen, R. L. Fields, S. L. Talbot, J. M. Pearce, and R. K. Chesser. 2001. Sex-biased gene flow in Spectacled Eiders (Anatidae): Inferences from molecular markers with contrasting modes of inheritance. Evolution 55:2105-2115.

Seutin, G., B. N. White, and P. T. Boag. 1991. Preservation of avian blood and tissue samples for DNA analyses. Canadian Journal of Zoology 69:82-90.

Shepherd, L. D., C. D. Millar, G. Ballard, D. G. Ainley, P. R. Wilson, G. D. Haynes, C. Baroni, and D. M. Lambert. 2005. Microevolution and mega-icebergs in the Antarctic. Proceedings of the National Academy of Sciences USA 102:16717-16722.

Slack, K. E., A. Janke, D. Penny, and U. Arnason. 2003. Two new avian mitochondrial genomes (penguin and goose) and a summary of bird and reptile mitogenomic features. Gene 302:4352.

Slatkin, M. 1995. A measure of population subdivision based on microsatellite allele frequencies. Genetics 139:457-462, 1463.

Slatkin, M., And L. Excoffier. 1996. Testing for linkage disequilibrium in genotypic data using the Expectation-Maximization algorithm. Heredity 76:377-383.

Smouse, P. E., J. C. Long, And R. R. SoKal. 1986. Multiple regression and correlation extensions of the Mantel test of matrix correspondence. Systematic Zoology 35:627-632. 
Stokes, D. L., ANd P. D. Boersma. 1998. Nest-site characteristics and reproductive success in Magellanic Penguins (Spheniscus magellanicus). Auk 115:34-49.

Stokes, D. L., AND P. D. Boersma. 2000. Nesting density and reproductive success in a colonial seabird, the Magellanic Penguin. Ecology 81:2878-2891.

Thumser, N. N., And J. D. Karron. 1994. Patterns of genetic polymorphism in five species of penguins. Auk 111:1018-1022.

Tsuda, T. T., M. Tsuda, T. Naruse, H. Kawata, A. Ando, T. Shinna, M. Fukuda, M. Kurita, I. Lemaho, J. K. Kulski, ANd H. INOKO. 2001. Phylogenetic analysis of penguin (Spheniscidae) species based on sequence variation in MHC class II genes. Immunogenetics 53:712-716.

Weir, B. S., and C. C. Cockerham. 1984. Estimating F-statistics for the analysis of population structure. Evolution 38:1358-1370

Williams, T. D. 1995. The Penguins. Oxford University Press, Oxford, United Kingdom.

Wright, S. W. 1978. Evolution and the Genetics of Populations, vol. 4: Variability within and among Natural Populations. University of Chicago Press, Chicago, Illinois.

Associate Editor: K. T. Scribner 
Reproduced with permission of the copyright owner. Further reproduction prohibited without permission. 